\section{ANALYSIS OF QUALITY CONTROL USING STATISTICAL PROCESS CONTROL (SPC) IN BREAD PRODUCTION}

\author{
Tika Endah Lestari' \\ Nabila Soraya Rahmat ${ }^{2}$ \\ Faculty of Engineering \\ Sampoerna University Jakarta ${ }^{1,2}$ \\ *E-mail: tika.lestari@sampoernauniversity.ac.id
}

Abstrak. Dalam penelitian ini, penulis melakukan analisis pengendalian kualitas roti menggunakan atribut P-chart untuk memenuhi statistik pengendalian kualitas. Populasi penelitian ini adalah semua jenis roti yang diproduksi oleh Roti Sari Wangi sebanyak delapan jenis roti dengan kapasitas produksi 1.600 bungkus per hari. Teknik pengambilan sampel dalam penelitian ini adalah penarikan sampel jenis roti berdasarkan judgment sampling dan random sampling. Roti Sari Wangi memproduksi delapan jenis roti, penulis hanya mengambil empat jenis produk roti. Dari uji normalitas menggunakan SPSS, kita dapat menyimpulkan bahwa keempat jenis roti ini masih dalam batas standar perusahaan. Namun, total biaya untuk cacat empat jenis roti adalah Rp4.302.000. Ini adalah angka tinggi untuk perusahaan kecil seperti yang diamati penulis.

Kata Kunci: Statistical Quality Control, Control Chart, Pchart, Bread production

\section{INDONESIAN JOURNAL OF FUNDAMENTAL SCIENCES (IJFS)}

\section{E-ISSN: 2621-6728 \\ P-ISSN: 2621-671X}

Submitted: June $11^{\text {th }}, 2018$

Accepted : July, $13^{\text {th }}, 2018$

Abstract. In this research, the writer does analyze quality control of bread using attributes $P$-chart to meet in quality control statistics. The population of this study was all types of bread produced by Roti Sari Wangi as many as eight types of bread with a production capacity of 1,600 packs per day. The sampling technique in this study was a withdrawal of bread type samples based on judgment sampling and random sampling when Roti Sari Wangi produced eight types of bread the writers only took four types of bread products. From the test normality using SPSS, we can conclude that these four kinds of bread are still in the standard limit of a company. However, the total costs for defect of four kinds of bread are IDR $4,302,000$. This is the high number for the small company like the writer observed. 


\section{INTRODUCTION}

The production process cannot be separated from consumers and resulting product. Consumers certainly hope that the items they buy will be able to meet their needs and desires so that consumers hope that these products have right and guaranteed conditions. Therefore, companies need to maintain that the quality of the products produced are guaranteed and accepted by consumers and can compete in the market. Excellent quality will generate trust from consumers. Meanwhile the production must pay more attention to the quality of the products result therefore required quality control to find out whether the product defects produced are still within limits. As we know quality control in companies both service companies and manufacturing companies is essential. The production hopes to attract consumers and can meet the needs and desires of consumers with the quality of services or goods produced.

Quality control that is carried out correctly will have an impact on the quality of the resulting product. The quality of the products produced by production is determined based on specific characteristics. Although the production processes have been carried out well, in reality, there are still errors that the quality of the product produced is not following the standard, or in other words, the product is damaged or defective in the product.

The result of the excellent quality of the product comes from good quality control. Many companies use specialized methods to produce good-quality products. For this reason, the quality control necessary to keep the product generated by the applicable quality standards. The company's quality standards are usually dependent on raw materials, production process, and the finished product (results). Therefore, the activities of quality control can be done starting from the selection of materials, the production process up to the final result in the form of products and customized by the standards set in the company.

Statistical Process Control (SPC) is the process control tool that is commonly used, this tool is often used to find out the source of variations in the control chart along with the analysis of process capabilities. In may statistical applications, control chart has important role to asses the "quality" of product; either in control or out of control (Lestari, 2015). Control Chart was first introduced by Dr. Walter Andrew Shewhart of Bell Telephone Laboratories, the United States, in 1924 intending to eliminate abnormal variations through separation of variations caused by the particular causes of variation and common causes. This variation means that the production process must be stable and capable of operating in such a way so that all products are produced according to specifications.

Quality requires an ongoing improvement process. Quality improvement can be appropriately made when the measured values are within the SPC approach 
expectations. The incompatibility of such quality characteristics net weight of the products will have an impact on the one hand, which the producer or the consumer. If the characteristics of the quality exceed the specifications of the manufacturer will be harmed, and if the characteristics under the specifications of the consumers will be harmed. By the research problem described before, the writer can conclude that the objectives of the study to analyze quality control of bread using attributes P-chart to meet in quality control statistics.

\section{MATERIAL AND METHODS}

The quality control used in research at the Bandung bakery production is carried out in an attribute that is the measurement of quality on product characteristics that cannot or are difficult to measure. The characteristics in question are good or bad product quality, success or failure. P-chart is an attribute quality measurement tool to calculate the proportion of existing defects. These control charts are used in attribute quality control that is to control the damaged product part of the production and to find out if it is still within tolerance.

The population of this study was all types of bread produced by Roti Sari Wangi as many as eight types of bread with a production capacity of 1,600 packs per day. Each model has generated 200 packages per day, resulting in a total population of 48,000 packages for 30 days ( 1 month). The sampling technique in this study was a withdrawal of bread type samples based on judgment sampling and random sampling when Roti Sari Wangi produced eight types of bread the writers only took four types of bread products. Types of bread that the writer took was chocolate bread, peanut bread, cheese bread and green bean bread (data report collected in April 2018). Data on production results that have been obtained will be processed using Statistical Quality Control (SQC) analysis using the P-charts (P-charts) Diagram method which is processed through Statistical Package for the Social Science (SPSS) application.

Statistical Process Control (SPC) is a problem-solving technique that is used as a monitor, controller, analyzer, manager and improves the process using statistical methods. Philosophy on the concept of statistical process quality control or better known as statistical process control (Statistical Process Control) is the output of a process or service can be expressed in statistical control through management tools and design actions. Statistical process control is the application of statistical methods for measurement and analysis of process variation. This technique is the parameters of the process and process analysis.

The goal of statistical process control is primarily to reduce variation or process errors. The primary objective in statistical process control is to detect assignable cause or special cause in variations or process errors through data analysis from the future or the future as well. The process variation consists of two 
kinds of reasons, namely the common purpose that has been attached to the process, and assignable cause or special cause which is an excessive error. Ideally, only general reasons are shown or appear in the process, because it shows that the process is in a stable and predictable condition. This condition shows minimum variation which defined as the non-uniformity of the product or service produced. Differences can also be defined as the product or service produced does not meet the standard specifications that have been set. Variations are grouped into two types:

1. Controllable Variation Controllable variations are variations that can be controlled or variations that can be removed or minimized if repairs are carried out. This type of variation is usually stable, consistent, likely random, predictable, naturally occurring, inherent, random causes. Examples of this type of variation are less like raw materials, less careful operators, and others.

2. Uncontrollable Variations Uncontrolled variations are uncontrollable variations. This type of variation is usually unstable, inconsistent, unpredictable, and generally occurs due to natural or environmental factors, causing system abnormalities and can be repaired locally. Examples of this type of variation are air humidity, changing room temperature, changes in voltage, etc.

The control chart is a graph used to study how a process changes over time. Data are plotted in time order. A control chart always has a central line for the average, an upper line for the upper control limit and a lower line for the lower control limit. These lines are determined from historical data. By comparing current data to these lines, you can draw conclusions about whether the process variation is consistent (in control) or is unpredictable (out of control, affected by special causes of variation).

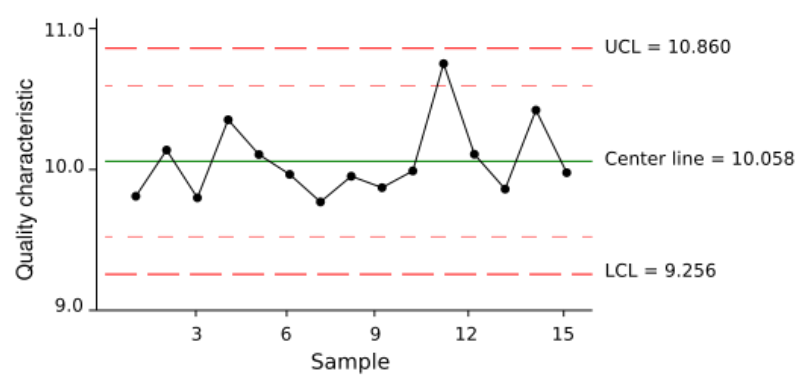

Figure. 1. Example for control chart

There are two different types of statistical quality control methods, that is Control Chart variables for quantitative data and Control Chart attributes for 


\section{Indonesian Journal of Fundamental Sciences Vol.4, No.2, October 2018}

qualitative data. Since the author got a data from the company was a qualitative data, so this thesis will using Control Chart attributes. This Attribute Control Chart is used to control the process by using Attribute Data such as Number of Units that Failed to Production (Reject), Number of employee absences, and Number of defective Components and so on. Attribute Data is Data that only has two values or choices such as OK or NG, Present or Absence, and Good Components or Defective Components. These types of Control Chart include np-Chart, $\mathrm{p}$-Chart, $\mathrm{c}$-Chart, and uChart.

\section{Control Chart Attributes (p-chart)}

P Control Chart (error proportion control) is one attribute Control Chart used to control defective product parts from production. Error proportion control ( $p$ chart) is used to find out whether the product defects produced are still within the required limits or not. It can also be said as a comparison between the number of errors with all observations, namely each product that is classified as "accepted" or "rejected" (which is considered the number of defective products).

Error proportion Control Charts are used if we use a defect size in the form of a proportion of defective products in each sample taken. If the sample taken for each observation is the same number, we can use the error proportion control chart ( $p$ chart) or the number of errors (np-chart). However, if the sample taken varies for each time, the observations change in or indeed the production will do $100 \%$ inspection then we must use an error proportion control chart ( $p$-chart).

If the sample taken for each time observation the amount is always the same or constant, then the steps to create a P control chart manually are as follows: The first step is determine a large enough sample size/subgroup ( $n>30)$, Collect the number of subgroups $(k)$ of at least 20 - 25 subgroups, Calculate for each subgroup the value of the proportion of defective units with the formula: $p=\frac{x}{n}$ where $\mathrm{p}$ is the proportion of errors in each sample, $x$ becomes the number of products that are wrong in each sample, and $\mathrm{n}$ is the number of samples taken in the inspection, Calculate the average value of $\mathrm{p}$ with formula (1):

$$
p=\frac{\text { Total defect product }}{\text { Total product inspected }}
$$

Calculate Upper Control Limit, Control Limit, and Lower Control Limit, with formula (2)

$$
\begin{aligned}
\mathrm{UCL} & =\bar{p}+3 \sqrt{\frac{\bar{p}(1-\bar{p})}{n}} \\
\mathrm{CL} & =\bar{p}
\end{aligned}
$$




$$
\mathrm{LCL}=\bar{p}-3 \sqrt{\frac{\bar{p}(1-\bar{p})}{n}}
$$

The last step to provide sample is plot the data on the proportion (percentage) of defective units and observe whether the information is under control or out of control. By the data that company given, the authors use the type attribute control chart in p-chart.

Rules, for detecting "out-of-control" (warning to be out of control data) or nonrandom conditions were first postulated by Walter A. Shewhart in the 1920 s Rules. These are the rules:

Table. 1. Control chart rules by Walter A. Shewhart

\begin{tabular}{|c|c|c|}
\hline Rule & Description & Problem Indicated \\
\hline Rule 1 & $\begin{array}{l}\text { One point is more than } 3 \text { standard } \\
\text { deviations from the mean. }\end{array}$ & $\begin{array}{l}\text { One sample (two } \\
\text { shown in this case) is } \\
\text { grossly out of control. }\end{array}$ \\
\hline Rule 2 & $\begin{array}{l}\text { Nine (or more) points in a row are on the } \\
\text { same side. }\end{array}$ & $\begin{array}{l}\text { Some prolonged bias } \\
\text { exists. }\end{array}$ \\
\hline Rule & Description & Problem Indicated \\
\hline Rule 3 & $\begin{array}{l}\text { Six (or more) points in a row are } \\
\text { continually increasing (or decreasing). }\end{array}$ & A trend exists. \\
\hline Rule 4 & $\begin{array}{l}\text { Fourteen (or more) points in a row } \\
\text { alternate in direction, increasing then } \\
\text { decreasing. }\end{array}$ & $\begin{array}{l}\text { This much oscillation is } \\
\text { beyond noise. This is } \\
\text { directional and the } \\
\text { position of the mean } \\
\text { and size of the } \\
\text { standard deviation do } \\
\text { not affect this rule. }\end{array}$ \\
\hline Rule 5 & $\begin{array}{l}\text { Two (or three) out of three points in a } \\
\text { row are more than } 2 \text { standard deviations } \\
\text { from the mean in the same directions. }\end{array}$ & $\begin{array}{l}\text { There is a medium } \\
\text { tendency for samples } \\
\text { to be mediumly out of } \\
\text { control. } \\
\text { The side of the mean } \\
\text { for the third point is } \\
\text { unspecified. }\end{array}$ \\
\hline Rule 6 & $\begin{array}{l}\text { Four (or five) out of five points in a row } \\
\text { are more than } 1 \text { standard deviation from }\end{array}$ & $\begin{array}{l}\text { There is a strong } \\
\text { tendency for samples }\end{array}$ \\
\hline
\end{tabular}




\begin{tabular}{|c|c|c|}
\hline & the mean in the same direction. & $\begin{array}{l}\text { to be slightly out of } \\
\text { control. } \\
\text { The side of the mean } \\
\text { for the fifth point is } \\
\text { unspecified. }\end{array}$ \\
\hline Rule 7 & $\begin{array}{l}\text { Fifteen points in a row are all within } 1 \\
\text { standard deviation of the mean on either } \\
\text { side of the mean. }\end{array}$ & $\begin{array}{l}\text { With } 1 \text { standard } \\
\text { deviation, greater } \\
\text { variation would be } \\
\text { expected. }\end{array}$ \\
\hline Rule 8 & $\begin{array}{l}\text { Eight points in a row exist with none } \\
\text { within } 1 \text { standard deviation of the mean } \\
\text { and the points are in both directions from } \\
\text { the mean. }\end{array}$ & $\begin{array}{l}\text { Jumping from above to } \\
\text { below whilst missing } \\
\text { the first standard } \\
\text { deviation band is rarely } \\
\text { random. }\end{array}$ \\
\hline
\end{tabular}

\section{RESULT AND DISCUSSION}

Quality control on the final result is an activity that checks the final product whether it is following the quality of the company standard. In this case, the company determines whether the product is suitable for sale to consumers and following company standards or not. As previously described, the first step taken to analyze quality control statistically is to make a table (check sheet) the amount of production and products damaged / not following quality standards. This Check sheet is used to simplify the process of data collection and analysis. This following table is the production data and the quality control of the process and final results during April 2018: 
Table. 2. Check Sheet for four kinds of bread

\begin{tabular}{|r|r|r|r|r|r|r|r|r|r|}
\hline \multirow{2}{*}{ Day } & \multirow{2}{*}{ Sample } & \multicolumn{2}{|c|}{ Choco } & \multicolumn{2}{|c|}{ Peanut } & \multicolumn{2}{c|}{ Cheese } & \multicolumn{2}{|c|}{ GreenPea } \\
\cline { 3 - 10 } & & Def & Prop & Def & Prop & Def & Prop & Def & Prop \\
\hline 1 & 200 & 20 & 0,1 & 13 & 0,065 & 12 & 0,06 & 15 & 0,075 \\
\hline 2 & 200 & 12 & 0,06 & 11 & 0,055 & 14 & 0,07 & 16 & 0,08 \\
\hline 3 & 200 & 10 & 0,05 & 15 & 0,075 & 15 & 0,075 & 11 & 0,055 \\
\hline 4 & 200 & 15 & 0,075 & 9 & 0,045 & 16 & 0,08 & 22 & 0,11 \\
\hline 5 & 200 & 9 & 0,045 & 7 & 0,035 & 14 & 0,07 & 12 & 0,06 \\
\hline 6 & 200 & 8 & 0,04 & 9 & 0,045 & 10 & 0,05 & 10 & 0,05 \\
\hline 7 & 200 & 14 & 0,07 & 12 & 0,06 & 9 & 0,045 & 13 & 0,065 \\
\hline 8 & 200 & 13 & 0,065 & 9 & 0,045 & 20 & 0,1 & 15 & 0,075 \\
\hline 9 & 200 & 16 & 0,08 & 14 & 0,07 & 21 & 0,105 & 15 & 0,075 \\
\hline 10 & 200 & 20 & 0,1 & 13 & 0,065 & 22 & 0,11 & 10 & 0,05 \\
\hline 11 & 200 & 6 & 0,03 & 20 & 0,1 & 13 & 0,065 & 21 & 0,105 \\
\hline 12 & 200 & 4 & 0,02 & 19 & 0,095 & 12 & 0,06 & 10 & 0,05 \\
\hline 13 & 200 & 12 & 0,06 & 18 & 0,09 & 10 & 0,05 & 9 & 0,045 \\
\hline 14 & 200 & 15 & 0,075 & 17 & 0,085 & 9 & 0,045 & 12 & 0,06 \\
\hline 15 & 200 & 14 & 0,07 & 16 & 0,08 & 18 & 0,09 & 13 & 0,065 \\
\hline 16 & 200 & 12 & 0,06 & 15 & 0,075 & 17 & 0,085 & 14 & 0,07 \\
\hline 17 & 200 & 10 & 0,05 & 14 & 0,07 & 16 & 0,08 & 13 & 0,065 \\
\hline 18 & 200 & 9 & 0,045 & 13 & 0,065 & 12 & 0,06 & 3 & 0,015 \\
\hline 19 & 200 & 8 & 0,04 & 12 & 0,06 & 11 & 0,055 & 13 & 0,065 \\
\hline 20 & 200 & 7 & 0,035 & 11 & 0,055 & 9 & 0,045 & 21 & 0,105 \\
\hline 21 & 200 & 5 & 0,025 & 10 & 0,05 & 8 & 0,04 & 13 & 0,065 \\
\hline 22 & 200 & 4 & 0,02 & 9 & 0,045 & 7 & 0,035 & 10 & 0,05 \\
\hline 23 & 200 & 3 & 0,015 & 8 & 0,04 & 6 & 0,03 & 9 & 0,045 \\
\hline 24 & 200 & 3 & 0,015 & 7 & 0,035 & 5 & 0,025 & 8 & 0,04 \\
\hline 25 & 200 & 20 & 0,1 & 6 & 0,03 & 12 & 0,06 & 7 & 0,035 \\
\hline 26 & 200 & 12 & 0,06 & 5 & 0,025 & 10 & 0,05 & 16 & 0,08 \\
\hline 27 & 200 & 15 & 0,075 & 4 & 0,02 & 9 & 0,045 & 13 & 0,065 \\
\hline 28 & 200 & 14 & 0,07 & 3 & 0,015 & 8 & 0,04 & 12 & 0,06 \\
\hline 29 & 200 & 15 & 0,075 & 12 & 0,06 & 14 & 0,07 & 21 & 0,105 \\
\hline 30 & 200 & 16 & 0,08 & 11 & 0,055 & 12 & 0,06 & 3 & 0,015 \\
\hline Totalyyyyyyyyyyyyy & 6000 & 341 & 1,705 & 342 & 1,71 & 371 & 1,855 & 380 & 1,9 \\
\hline & & & & & & & \\
\hline
\end{tabular}

From Table. 2, we can calculate the total defect of four kinds of all of bread that the writer observe, we get 1434 bread is failed to sell and the total loss is IDR 4,302,000 for a month. The writer only observes four kinds of bread out of eight types of bread, this means the estimate of loss in the company for a month is IDR $8,604,000$. In carrying out production quality control activities, the company places supervisors to oversee the actions in the production process and the final results. The supervisors include workers appointed by the leadership. Quality control of the of bread products is using statistical quality control (SQC) applying the p-charts method which is processed through the Statistical Package for the Social Sciences (SPSS) software. Discussion of each type of bread product produced at the Roti Sari Wangi Bandung Company as follows: 


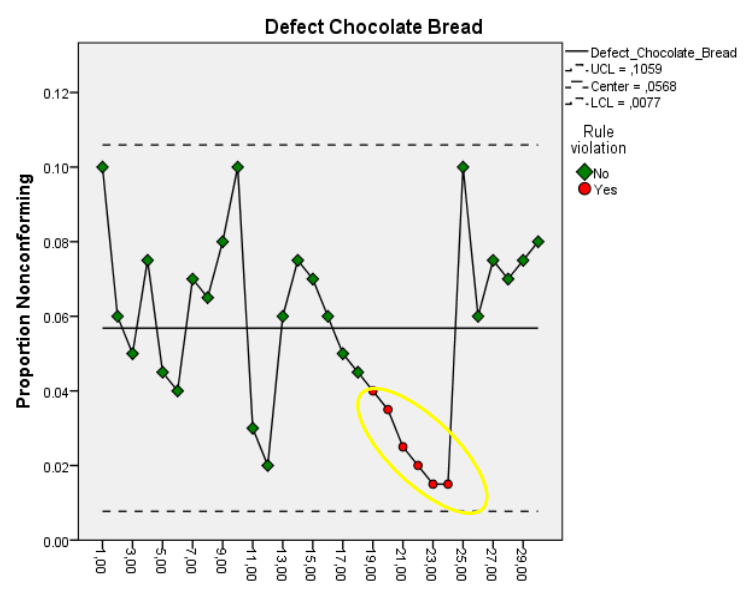

Figure. 2. P-Chart for proportion defect chocolate bread

Chocolate bread type, from the results of data processing, shows the value of the central line is 0.0568 or $5.68 \%$, the upper control limit value (UCL) is 0.1059 or $10.59 \%$ which means if the defective or damaged product reaches or above the upper control limit (UCL) the chocolate bread production is ineffective. Similarly, the defective or damaged product is at the lower control limit ( $L C L)$ indicating a value of 0.0077 or $0.77 \%$ means that the production process of chocolate type bread is not effective enough. As mention before that the price of bread is IDR 3000 each, we can calculate that the Chocolate bread has a loss IDR 1,023,000 a month and IDR 34,100 each day.

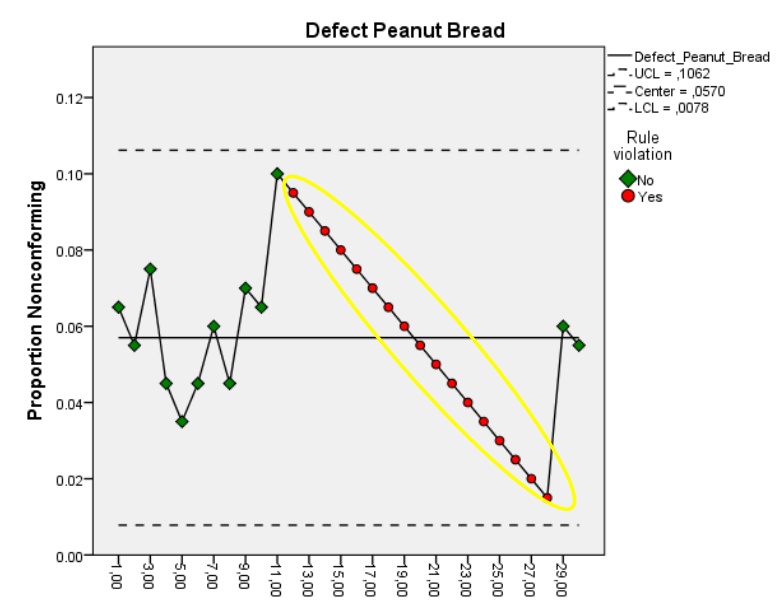

Figure. 3. P-Chart for proportion defect peanut bread

Peanut bread type, from the results of data processing in Figure. 3, shows the value of the central line is 0.0570 or $5.70 \%$, the upper control limit value (UCL) is 0.1062 or $10.62 \%$ which means if the defective or damaged product reaches or above 
the upper control limit (UCL) the peanut bread production is ineffective. Similarly, the defective or damaged product is at the lower control limit ( $L C L$ ) indicating a value of 0.0078 or $0.78 \%$ means that the production process of peanut type bread is not effective enough. As mention before that the price of bread is IDR 3000 each, we can calculate that the peanut bread has a loss IDR 1,026,000 a month and IDR 34,200 each day.

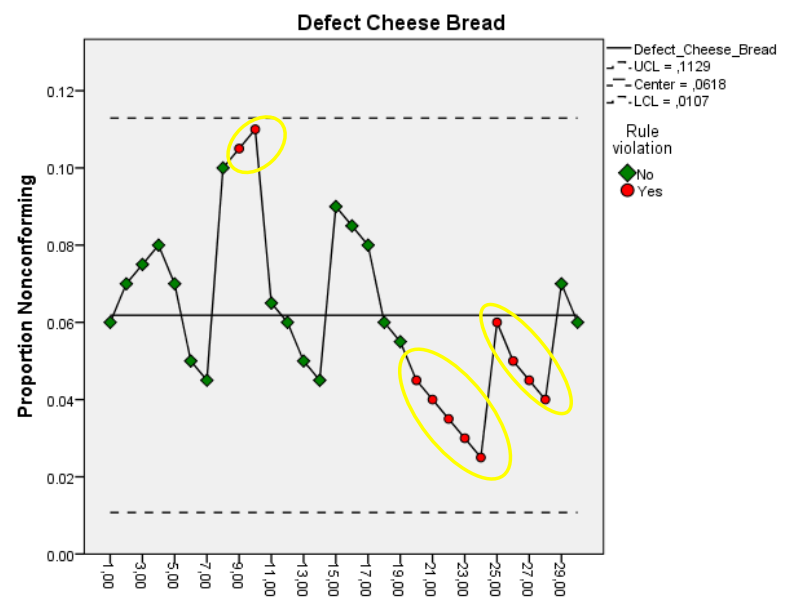

Figure. 4. P-Chart for proportion defect cheese bread

Cheese bread type, from the results of data processing on Figure. 4, shows the value of the central line is 0.0618 or $6.18 \%$, the upper control limit value (UCL) is 0.1129 or $11.29 \%$ which means if the defective or damaged product reaches or above the upper control limit (UCL) the cheese bread production is ineffective. Similarly, the defective or damaged product is at the lower control limit (LCL) indicating a value of 0.0107 or $1.07 \%$ means that the production process of cheese type bread is not effective enough. As mention before that the price of bread is IDR 3000 each, we can calculate that the cheese bread has a loss IDR 1,113,000 a month and IDR 37,100 each day.

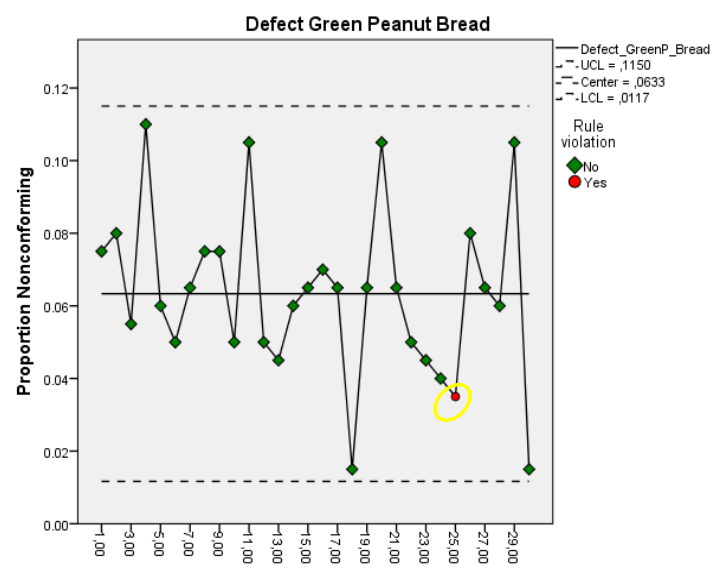

Figure. 5. P-Chart for proportion defect green peanut bread 
Green peanut bread type, from the results of data processing, shows the value of the central line is 0.0633 or $6,33 \%$, the upper control limit value (UCL) is 0.1150 or $11,50 \%$ which means if the defective or damaged product reaches or above the upper control limit (UCL) the green peanut bread production is ineffective. Similarly, the defective or damaged product is at the lower control limit ( $L C L$ ) indicating a value of 0.0117 or $1.17 \%$ means that the production process of green peanut type bread is not effective enough. As mention before that the price of bread is IDR 3000 each, we can calculate that the peanut bread has a loss IDR 1,140,000 a month and IDR 38,000 each day.

Table. 3. Test of normality for four kinds of bread

Tests of Normality

\begin{tabular}{|l|r|r|r|r|r|r|}
\hline & \multicolumn{3}{|c|}{ Kolmogorov-Smirnovi } & \multicolumn{3}{c|}{ Shapiro-Wilk } \\
\cline { 2 - 7 } & Statistic & \multicolumn{1}{c|}{ df } & \multicolumn{1}{c|}{ Sig. } & Statistic & \multicolumn{1}{c|}{ df } & \multicolumn{1}{c|}{ Sig. } \\
\hline Chocolate & .117 & 30 & .200 & .955 & 30 & .230 \\
Green Peanut & .138 & 30 & .148 & .948 & 30 & .152 \\
Peanut & .076 & 30 & .200 & .987 & 30 & .964 \\
Cheese & .134 & 30 & .181 & .963 & 30 & .366 \\
\hline
\end{tabular}

The resulting test of normality for four kinds of bread, the probabilities which are squared in red means that if the number is less than 0.05 means four kinds of bread are in control data and the data are normal.

\section{CONCLUSION}

By the research problem described before, the writer can conclude that the objectives of the study to analyze quality control of bread using attributes P-chart to meet in quality control statistics. In this study the method that the writer applied for knowing the production process of Roti Sari Wangi is in control or not, and as mention before the production of Roti Sari Wangi is in control. Since we mention about Shewhart rules before, so we can assume that the "out of control" red dot in figure 2 , figure 3 , figure 4 , and figure 5 are warning for the companies for pay more attention in that day.

If we calculate the total defect of four kinds of all of bread that the writer observes, we get 1434 bread is failed to sell and the total loss is IDR 4,302,000 for a month. The writer only observes four kinds of bread out of eight types of bread, this mean the estimate of loss in the company for a month is IDR 8,604,000. This is a lot of money reminding the company that the writer observe is a small company. As mention before that, the price of bread is IDR 3000 each, we can calculate that the peanut bread has the highest loss IDR 1,140,000 a month and IDR 38,000 each day. 


\section{REFERENCES}

Feigenbaum, A V (1945), “Quality Control: Principles, Practice and Administration; an industrial management tool for improving product quality and design and for reducing operating costs and losses."

Goetsch, D.L. \& Davis, S. (1994). "Introduction to Total Quality: Quality, Productivity, Competitiveness."

Kilian, Cecelia S. (1992). "The World of W. Edwards Deming (2nd ed.)". SPC Press, Inc.

Lestari, Tika. (2015). "Bivariate Control Chart With Copula". AIP Conference Proceedings. 1692(1), 020017.

Lloyd S. Nelson, "Technical Aids," Journal of Quality Technology 16, no. 4 (October 1984), 238-239.

McNeese, William (2006). “Over-controlling a Process: The Funnel Experiment”. BPI Consulting, LLC.

Montgomery, D.C. (1990). “Introduction To Statistical Quality Control”. New York

Nancy R. Tague (2004). "Seven Basic Quality Tools". The Quality Toolbox. Milwaukee, Wisconsin: American Society for Quality. p. 15. 